\title{
Makna Perempuan dalam Khazanah Turas Pesantren (Kritik Sastra Feminis)
}

\author{
Wahyu Hanafi Putra ${ }^{1}$ \\ Lisma Meilia Wijayanti²
}

\section{Institut Agama Islam Sunan Giri (INSURI) Ponorogo}

1wahyu_hanss@insuriponorogo.ac.id

2Lismamei@gmail.com

\begin{abstract}
Abstrak
Penelitian ini bertujuan mendeskripsikan kritik sastra feminis dalam khazanah turas pesantren, dalam hal ini adalah kitab 'Uqūd Al-Lijain. Jenis penelitian adalah kualitatif dengan menggunakan pendekatan library-research. Data primer yang diambil adalah kitab 'Uqūd Al-Lijain karya Syaikh Nawawi Al-Bantani khususnya yang membahas perempuan. Kitab 'Uqūd Al-Lijain merupakan salah satu kitab turas yang banyak dipelajari santri di pesantren. Data sekunder diambil dari literatur-literatur yang berkaitan dengan perempuan, baik dari kitab maupun buku-buku ilmiah. Teknik pengumpulan data menggunakan dokumentasi, yaitu dengan mengumpulkan dan memilah teks yang membahas perempuan dalam kitab-kitab tersebut kemudian mengelompokkan dalam beberapa variabel untuk dilakukan analisis. Analisis data dilakukan dengan reduksi data makna perempuan dalam kitab 'Uqūd Al-Lijain, menyajikan data, kemudian menganalisisnya dengan pendekatan kritik sastra feminis. Hasil penelitian menunjukkan bahwa kritik sastra feminis memberikan komentar atas perilaku laki-laki yang mendiskreditkan dan memposisikan perempuan sebagai makhluk marginal karena alasan berkarier, melayani suami, keluar rumah, menolak berhias, dan bersenggama. Perilaku demikian sudah tidak relevan di masa kini karena perkembangan ilmu pengetahuan dan teknologi semakin cepat, pertumbuhan ekonomi semakin meningkat, pranata dan strukur sosial berkembang yang membawa budaya populer semakin diadopsi oleh masyarakat. Perempuan memiliki peran yang sama dengan laki-laki. Saat ini perempuan tidak dapat diisolasi seperti masa klasik karena perempuan banyak mengambil alih peran laki-laki dalam berbagai bidang. Dengan demikian, kritik sastra feminis atas peran perempuan dalam kitab 'Uqūd Al-Lijain dapat menjadi solusi untuk menjalani kehidupan di masa kini. Di mana antara laki-laki dan perempuan memiliki peran yang sama sebagai makhluk sosial.
\end{abstract}

Kata kunci: Perempuan, Turas, Kritik Sastra Feminis

\section{Pendahuluan}

Perempuan memiliki diskursus yang sering diperdebatkan dalam berbagai perspektif. Tidak hanya isu gender, ekesistensi perempuan memiliki cakupan wacana yang begitu kompleks. Peran perempuan yang memiliki normativitas sebagai wakil dan pembantu, kini seharusnya telah diubah. Aktivis perempuan Amerika (Naomi, 1994) memandang paradigma penilaian sosial yang keliru adalah memandang laki-laki lebih baik daripada perempuan. Ketidakadilan secara patriarki inilah yang menyebabkan perempuan tidak memiliki reposisi layakya laki-laki (Humm, 2003). Secara sosial, perempuan akan menempati status marginal, perannya adalah sebagai pelengkap kehidupan laki-laki.

Dalam frame teologi Islam klasik, peran perempuan terbentuk dari kesejarahan yang sangat panjang (Tabroni, 2019). Terbentuknya peran perempuan tidak lepas dari 
persengketaan status sosial manusia, hakikat filsafat moral, dan kritik liberal atas peran perempuan (Tong, 2013). Perempuan lebih mengutamakan pencapaian persamaan derajat dengan laki-laki sebagai hal yang keliru (Gandhi, 2020), dampaknya adalah kecenderungan mengabaikan kodratnya sendiri sebagai perempuan. Peran perempuan dan laki-laki memiliki perbedaan kodrati terhadap realitas sosial. Pada posisi ini, Tuhan sebagai pencipta manusia (laki-laki dan perempuan) dengan memiliki peran yang sama dan fungsi yang berbeda. Lebih lanjut filsafat moral menyebut hakikat manusia adalah menjalankan tugas individu dan sosial di bumi sesuai kodratnya. Kedua insan demikian akan mendapat posisi sesuai dengan yang diembannya.

Diskursus perempuan terutama di Indonesia memiliki entitas dan unlimited. Hal tersebut karena dalam negara-negara demokrasi, hak asasi manusia menjadi paradigma fundamental guna menentukan kebijakan-kebijakan yang mengarah pada aspek kepribadian dan sosial (Tong, 2013). Perempuan sebagai objek penopang kehidupan lakilaki dalam menjalankan tugasnya tidak sebatas pada kemampuan fisik dan moral, namun kemampuan manajerial yang qualified sangat dibutuhkan guna membangun peradaban bangsa dan bernegara. Dalam membangun peradaban bangsa dan bernegara tidak hanya dimainkan oleh laki-laki, namun juga perempuan. Maka hasil kolaborasi SDM yang baik dari jati diri laki-laki dan perempuan akan melahirkan perubahan-perubahan bangsa yang progresif.

Pesantren dengan segala atensinya telah menempatkan perempuan dalam martabat yang tinggi seiring dengan nilai-nilai Islam. Atensi ini memberi bukti bahwa pesantren turut peduli dengan gerak perempuan, seperti pemberdayaan perempuan dalam memimpin pesantren, menjadi pengurus, dan staf (Prasetiawan \& Lis, 2019). Peran perempuan dan feminisme pesantren tersubordinasi dengan kerangka fungsional, artinya perempuan mendapatakan ruangan untuk berpartisipasi dalam proses perubahan pesantren yang lebih baik (Nuroniyah, 2019). Tujuan dari hal itu agar perempuan memiliki peran yang egaliter, kesetaraan, dan keadilan yang melahirkan kepribadian baik dan tidak bertentangan dengan normativitas Islam. Dengan terselenggaranya pemberdayaan perempuan pesantren, maka perempuan dapat berperan aktif dalam kompleksitas sosial kehidupan tanpa meninggalkan nilai-nilai spiritual yang dipelajari (Ratnasari, 2016).

Bertolak dari argumen di atas, saat ini masih banyak perempuan di pesantren yang terindoktrinasi dengan diskursus tradisional bahwa egaliter perempuan perlu dipertimbangkan. Corak kajian kitab turas (kitab kuning) yang banyak memengaruhi paradigma sensualitas perempuan menjadi faktor pemicu tumbuhnya idealisme tradisional perempuan pesantren (Ratnasari, 2016). Stimulus pesantren terhadap kaum perempuan cenderung konservatif dan preventif terutama pada diskursus-diskursus leberal yang diusung para tokoh liberalisme (Akib, 2019), karena moderasi agama yang dibentuk dalam pesantren adalah moderasi Islam eksklusif, bukan Islam inklusif. Harkat perempuan moderat menurut pesantren adalah perempuan yang terhindar dari isu skolastik, purifikatif, dan inklusif. Dengan paradigma demikian, perempuan pesantren terdistorsi dengan isu-isu gender. Gerak perempuan dalam pesantren tidak lebih dari sosok yang hanya menempati ruang belajar. Isu-isu inilah yang dijadikan dasar para aktivis perempuan untuk menempatkan perempuan secara adil dan egaliter sesuai dengan peran dan fungsinya, meskipun perempuan tersebut berdomisili di lembaga tertentu.

Distorsi peran perempuan dalam tradisi pesantren telah membawa pada gerakan feminisme. Gerakan feminisme dalam pesantren merupakan upaya rekonstruksi peran dan fungsi perempuan dalam mengendalikan, memanajerial, dan menentukan kebijakan- 
kebijakan yang penting di pesantren. Hal tersebutalah yang harus dilakukan. Pesantren dengan kurikulumnya secara eksplisit telah mengajarkan nilai-nilai egaliter dan kesetaraan gender melalui kajian-kajian kitab kuning yang bersifat interdisipliner seperti kitab-kitab susastra pesantren. Kajian susastra pesantren dinilai sangat objektif, mampu mereduksi sosio-kultural pesantren dengan narasi-narasi aforime seperti adanya kritik sastra feminis.

Diskursus feminisme dalam studi sastra terkenal dengan istilah kritik sastra feminis. Feminisme sendiri mengandung arti gerakan persamaan antara laki-laki dan perempuan di segala bidang baik politik, ekonomi, pendidikan, sosial, dan kegiatan terorganisasi yang mempertahankan hak-hak serta kepentingan perempuan (Ernst \& Horwath, 2014). Feminisme juga merupakan kesadaran akan penindasan dan pemerasan terhadap perempuan dalam masyarakat, baik di tempat kerja dan rumah tangga (Sugihastuti, 2002). Jika dilihat dengan frame sosial, feminisme adalah studi sosial yang melibatkan perempuan-perempuan yang tertindas karena budaya partiarkhi (Ernst \& Horwath, 2014). Feminisme berupaya mendudukkan perempuan untuk meraih perannya dalam pranata sosial dan terlepas dari kedudukan yang dinilai diskredit untuk berperan. Wilayahnya cukup kompleks, baik di bidang budaya, politik, pendidikan, hukum, dan leadership (Naomi, 1994). Namun hingga kini gerakan tersebut sejatinya belum menempati posisi yang maksimal. Dominasi laki-laki (maskulinisme) dalam berbagai bidang masih sangat kuat dan acapkali menjadi rekognisi pranata sosial. Hal tersebut menjadikan kelemahan bagi perempuan untuk berperan dan berekspresi sesuai kodratnya. Relasi-kuasa yang didominasi laki-laki sejatinya tidak dapat menyelesaikan berbagai masalah tanpa melibatkan perempuan. Terlebih jika kontradiksi fenomena sosial yang berlaku dalam wilayah tertentu masih sangat mengakar kuat (Naomi, 1994). Wacana demikian yang kemudian membawa pada diskursus kritik sastra feminis.

Sholwalter menyebut kritik sastra feminis sebagai studi sastra yang terfokus pada perempuan (Madsen, 2000). Jika selama ini dianggap dengan sendirinya bahwa yang mewakili pembaca dan pencipta dalam sastra barat ialah laki-laki, kritik sastra feminis menunjukkan perempuan membawa persepsi dan harapan ke dalam pengalaman sastranya (Soenarjati, 2010). Yoder menyebut bahwa kritik sastra feminis bukan berarti seorang pengritik yang berjenis kelamin perempuan, atau kritik tentang perempuan. Arti sederhana kritik sastra feminis adalah pengritik memandang sastra dengan kesadaran khusus bahwa terdapat banyak jenis kelamin yang berhubungan dengan budaya, sastra, dan kehidupan kita. Jenis kelamin inilah yang membuat perbedaan di antara diri pengarang, pembaca, perwatakan, dan faktor luar yang memengaruhi situasi karangmengarang (Rokhmansyah, 2014).

Kritik sastra feminis dapat dibedakan menjadi dua aliran, yaitu kritik sastra feminis berdasarkan ideologi atau kritik ideologis, dan kritik yang mengkaji penulispenulis perempuan (Humm, 2003). Kritik ideologis menempatkan pembaca perempuan sebagai sumber, sehingga pusat perhatiannya adalah citra dan stereotipe perempuan dalam karya sastra. Sementara kritik sastra yang lain memusatkan perhatian pada berbagai gejala yang dimiliki para pengarang perempuan, sehingga pengkajiannya dapat ditujukan kepada sejarah karya sastra perempuan, gaya kepenulisan, tema, genre, dan struktur tulisan para pengarang perempuan (Yudono, 2009).

Dasar pemikiran penelitian sastra perspektif feminis adalah upaya pemahaman kedudukan dan peran perempuan seperti tercermin dalam karya sastra (Gandhi, 2020). Peran dan kedudukan perempuan tersebut akan menjadi sentral pembahasan penelitian sastra. Peneliti akan memperhatikan dominasi laki-laki atau gerakan perempuan. Melalui studi dominasi tersebut, peneliti dapat memfokuskan kajian pada 1) kedudukan dan 
peran tokoh perempuan dalam sastra, 2) ketertinggalan kaum perempuan dalam segala aspek kehidupan, termasuk pendidikan dan aktivitas kemasyarakatan, 3) memperhatikan faktor pembaca sastra, khususnya tanggapan pembaca terhadap emansipasi perempuan dalam sastra (Endaswara, 2011).

Beranjak pada paradigma di atas, dapat diketahui bahwa perjalanan sastra feminis telah melalui exploration of konowledge dalam berbagai dimensinya (Goodman, 2013). Penelitian sastra feminis tidak hanya terfokus pada satu posisi perempuan. Kompleksitas dimensi posisi perempuan sebagai insan perubah wajah peradaban sosial, politik, pendidikan, dan hukum perlu dikaji secara aplikatif dan tidak sebatas teori-teori. Selain itu, perlu diberikan ruang pada perempuan guna menguatkan dedikasi dan loyalitas mereka. Perempuan dalam khazanah sastra feminis ibarat buah yang dibugkus dan tidak dapat dinikmati. Ketika buah itu dibuka, maka buah akan dapat dirasa semua orang.

Jika melacak historisitas kritik sastra feminis, awalnya terjadi di Amerika pada tahun 1960-an (Goodman, 2013). Sebuah survei menunjukkan bahwa beberapa pengecualian kanon sastra negeri itu merupakan tulisan laki-laki, bahkan ditemukan dalam jumlah besar bentuk sastra dari kurun waktu ke waktu hingga berabad-abad, bahwa dalam sejarah sastra Amerika tidak satupun menyinggung penulis perempuan. Hasil survei menyebabkan banyak pengamat sastra negeri itu termasuk, terutama kaum perempuan bertanya-tanya. Sehingga terjadilah serangkaian usaha untuk menggali kembali kekayaan sastra Amerika, membongkar untuk mengetahui apakah terdapat karya sastra perempuan yang dinilai penting dan tidak tercatat karena faktor dominasi para penulis sastra adalah laki-laki (Soenarjati, 2010). Jika lintasan sejarah sastra feminis mengatakan demikian, maka sangat ironi bahwa perempuan tidak memiliki reposisi kodrati. Ibarat kaum proletar yag harus mengabdi kepada kaum borjuis. Perempuan tidak memiliki ruang untuk merevitalisasi ideologi yang dimiliki dengan sebuah karya sastra. Hasilnya, segala wacana akan ditentukan dengan kebijakan laki-laki (maskulin) dan menihilkan perempuan (feminim).

\section{Metode}

Jenis penelitian ini adalah penelitian kualitatif dengan menggunakan pendekatan library-research. Sebagai penelitian library research, data primer yang diambil adalah kitab 'Uqūd Al-Lijain karya Syaikh Nawawi Al-Bantani khususnya yang membahas perempuan. Kitab 'Uqūd Al-Lijain merupakan salah satu kitab turas yang banyak dipelajari santri di pesantren. Data sekunder dalam penelitian ini adalah literatur-literatur yang berkaitan dengan perempuan baik dari kitab maupun buku-buku ilmiah. Teknik pengumpulan data menggunakan dokumentasi, yaitu peneliti mengumpulkan dan memilah teks-teks yang membahas perempuan dalam kitab-kitab tersebut kemudian mengelompokkan dalam beberapa variabel untuk dilakukan tahap analisis lebih lanjut. Analisis data dilakukan dengan reduksi data makna perempuan dalam kitab 'Uqūd AlLijain, menyajikan data tersebut kemudian menganalisisnya dengan pendekatan kritik sastra feminis (Ernst \& Horwath, 2014). 


\section{Hasil}

\section{Persepsi Perempuan dalam Kitab Uqūd al-Lijain}

Imam Nawawi al-Bantanī menyinggung persoalan perempuan karier atau perempuan bekerja dalam kitabnya tersebut. Dalam menjelaskan persoalan perempuan bekerja, beliau mengutip (QS. 34:4) dan menjelaskan sebagaimana berikut:

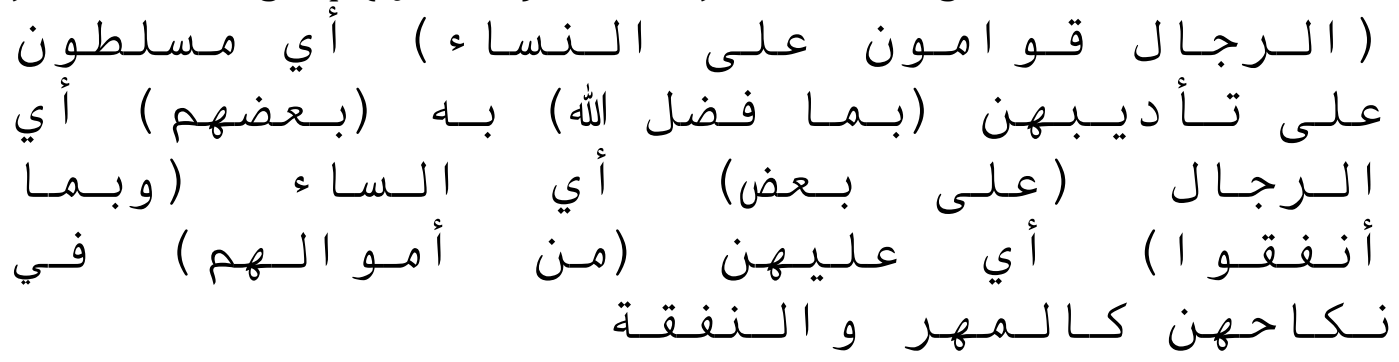

Maksud daripada kaum laki-laki sebagai pemimpin kaum perempuan yaitu suami memiliki kekuasaan untuk mendidik istri. Allah Swt melebihkan lakilaki atas perempuan karena kaum laki-laki yang dalam hal ini disebut suami tengah memberi harta perkawinan kepada kaum perempuan yang dalam hal ini disebut istri yakni berupa nafkah dan mas kawin (Nawawi, 2015)

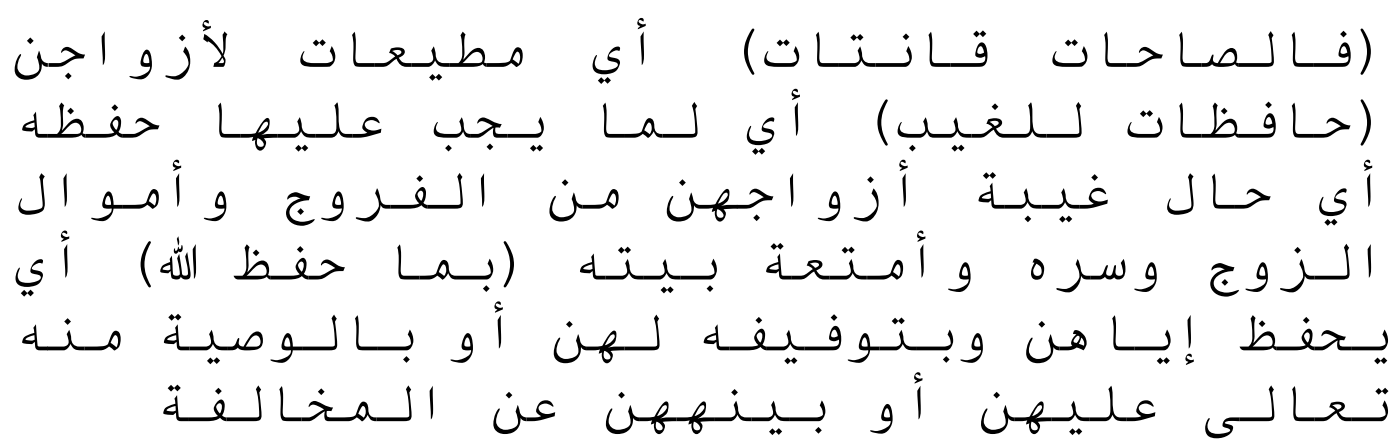

Perempuan-perempuan yang shalihah adalah mereka yang taat kepada suami. Mereka melaksanakan dan menunaikan kewajibannya saat suami tidak berada di rumah dengan menjaga kehormatannya, menjaga rahasia, dan menjaga harta suami sesuai dengan ketentuan-ketentuan yang diajarkan oleh Allah Swt, karena Allah Swt tengah menjaga dan memberikan pertolongan kepada mereka (Nawawi, 2015).

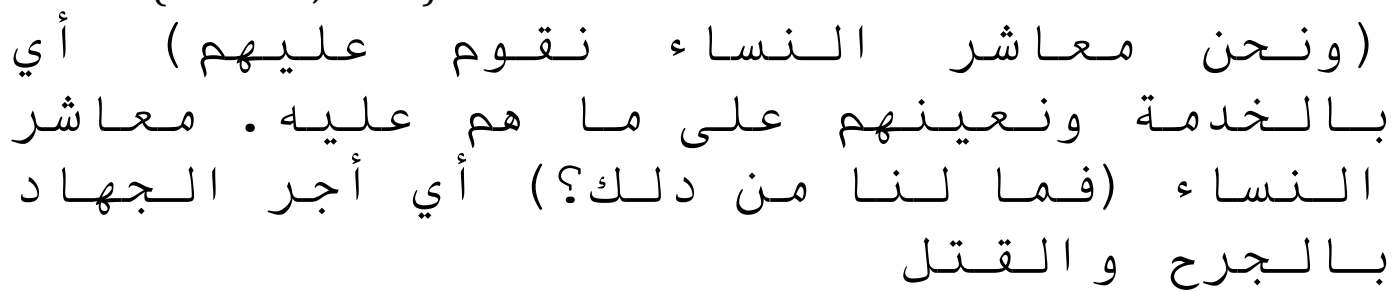

Didapati seorang yang datang kepada Nabi Muhammad saw seraya berkata: "wahai Rasulullah! Saya utusan kaum perempuan untuk datang menghadap engkau. Saya diutus untuk bertanya tentang peran perempuan dalam berjihad di jalan Allah Swt, dan bagaiana pahala jihad bagi saya dan kaum perempuan dalam melaksanakan jihad? (Nawawi, 2015)

Dalam membahas perempuan karier atau istri yang bekerja di luar, Imam Nawawi memberikan komentar dalam kitabnya tersebut. 


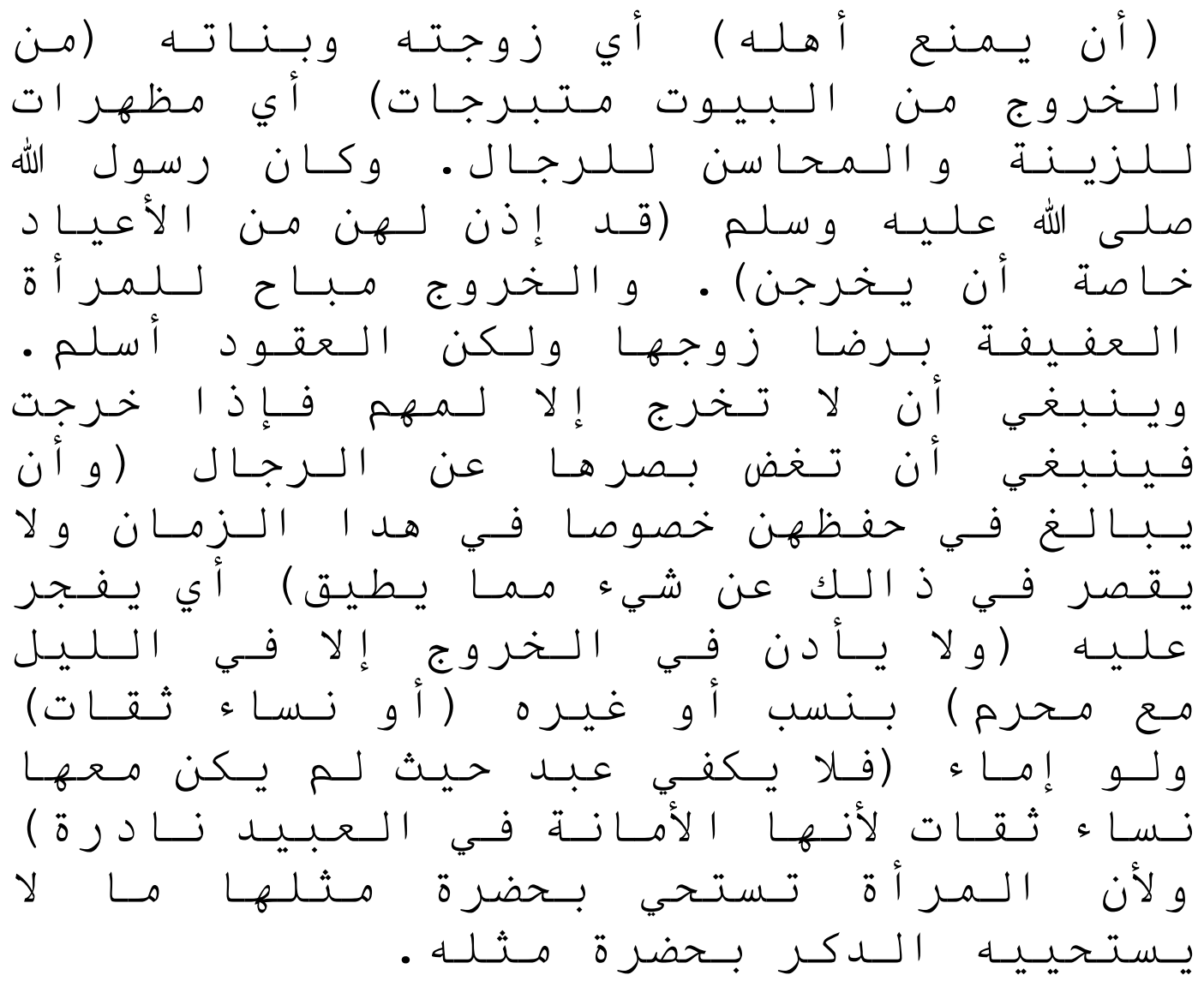

Seorang suami dapat melarang istri dan anak perempuannya keluar rumah dengan bersolek, yaitu menampakkan perhiasan dan kecantikannya di hadapan kaum laki-laki. Suatu saat, Rasulullah saw pernah memberi izin kepada istri-istri dan anak-anaknya untuk keluar rumah pada hari-hari besar Islam. Hukum keluar rumah bagi istri yang konsisten menjaga harga dirinya adalah diperbolehkan dengan syarat mendapat izin dari suami. Hendaknya istri tidak keluar rumah kecuali ada perihal penting yang harus diselesaikan. Jikapun ia keluar rumah, maka untuk senantiasa menundukkan mata di hadapan laki-laki. Istri harus mengoptimalkan menjaga diri dan harga dirinya terutama di zaman ini, di mana godaan lebih banyak dijumpai. Suami untuk tidak memberi izin istri keluar rumah di malam hari kecuali didampingi oleh mahram meskipun istri tersebut dapat dipercaya. Hal ini juga berlaku bagi hamba sahaya perempuan, yaitu harus senantiasa mendapat izin dari Tuannya disaat keluar rumah malam hari (Nawawi, 2015).

Dalam permasalahan perlakuan istri kepada suami, (Nawawi, 2015) memberikan penjelasan sebagaimana berikut:

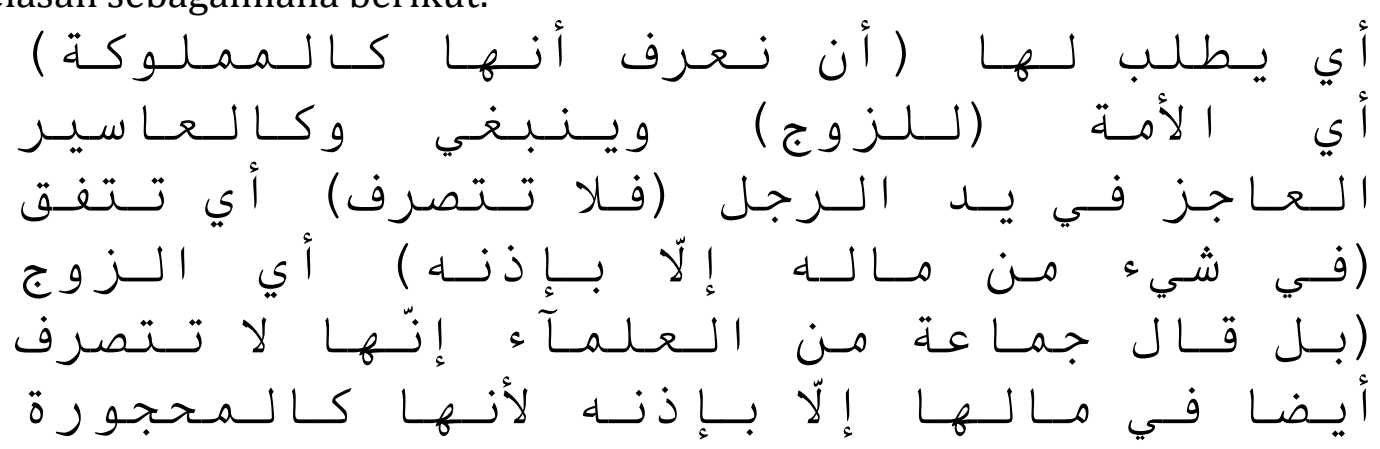




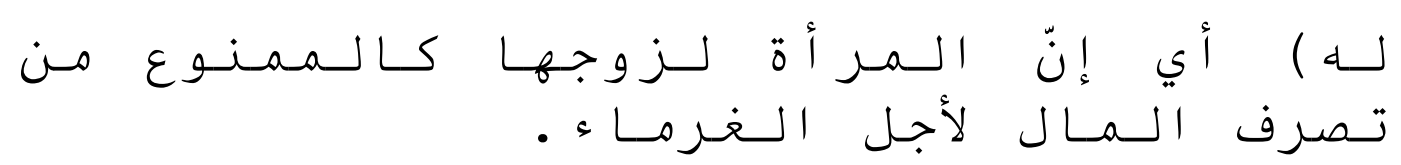

Seyogyanya (sunah) seorang istri mengetahui dan menempatkan dirinya seperti hamba sahaya/budak terhadap suaminya, atau seperti tawanan dalam kuasa seorang. Istri tidak diperbolehkan menafkahkan harta suaminya tanpa seizinnya. Ulama mengatakan, bahkan seorang istri tidak diperkenankan mentasarrufkan hartanya sendiri kecuali atas izin suaminya, karena ia laksana orang yang ditahan tasarrufnya.

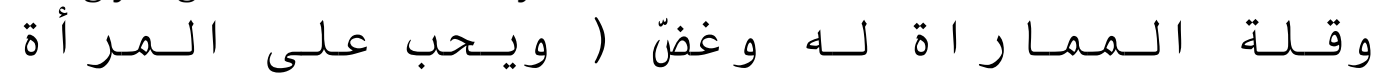

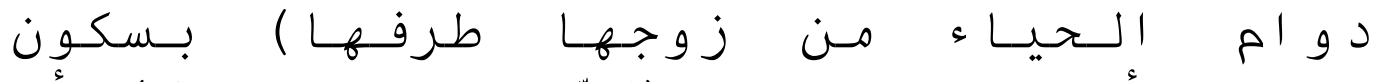

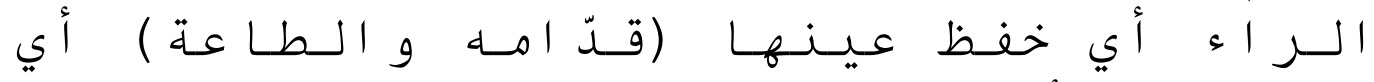

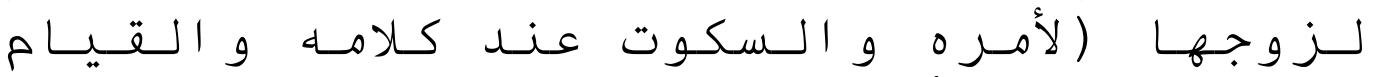

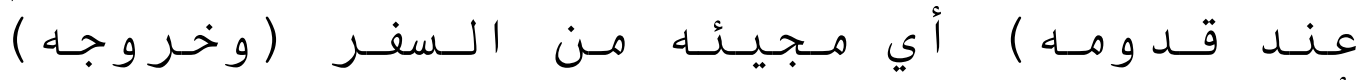

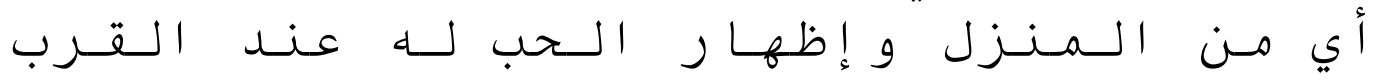

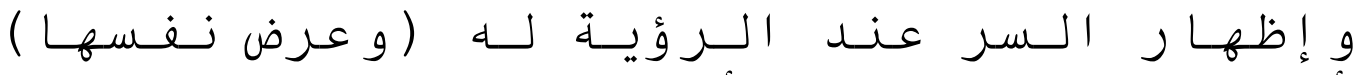

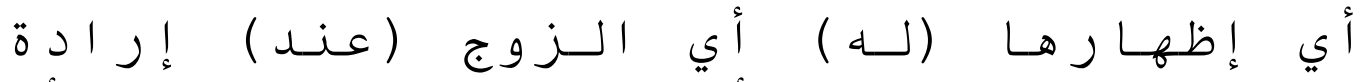

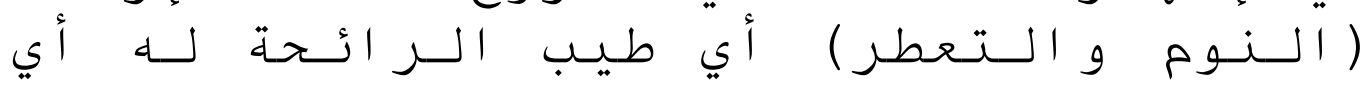

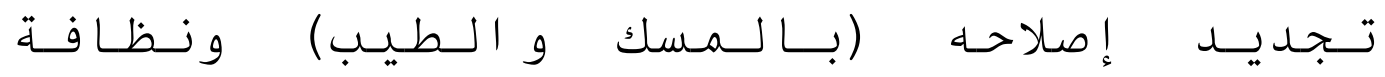

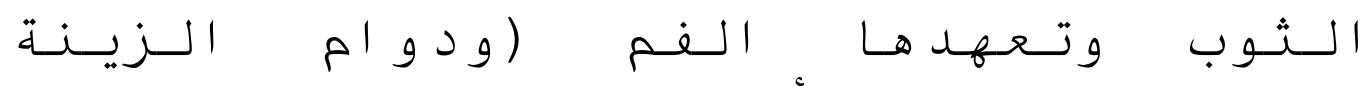

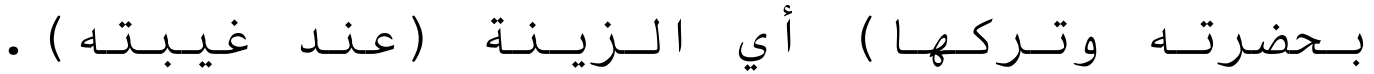

Dan wajib bagi seorang istri untuk memelihara rasa malu kepada suaminya, menundukkan kepala, menurunkan pandangan di depan suami, menuruti semua perintah suami, diam ketika suami berbicara, berdiri menyambut suami saat datang, mengantar suami sampai pintu depan rumah ketika suami hendak pergi, menampakkan sikap cinta di dekat suami, menyerahkan diri (pasrah) di hadapan suami saat tidur, menggunakan wewangian (parfum), menjaga dan membersihkan mulut saat hendak berbicara dengan suami, mengenakan pakaian yang bagus, mempercantik diri saat bersama suami, dan meninggalkan bersolek saat suami tidak di rumah.

Dalam permasalahan keluar rumah, (Nawawi, 2015) memberi batasan kepada perempuan yang hendak melakukannya:

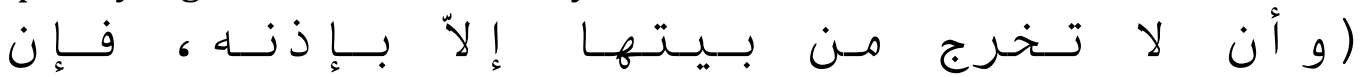

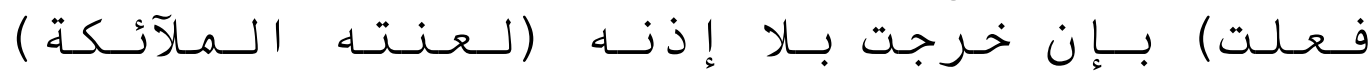

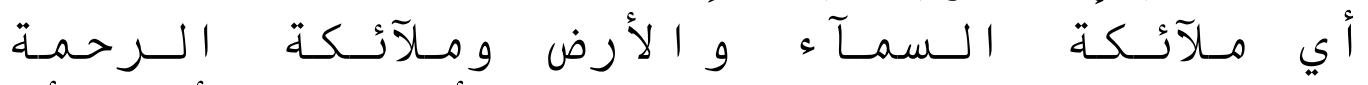

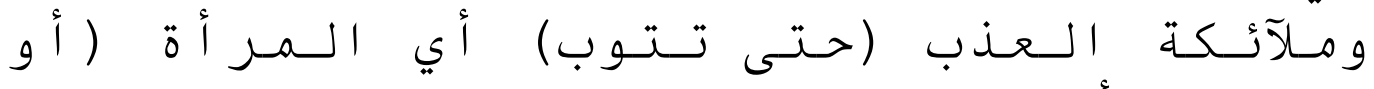

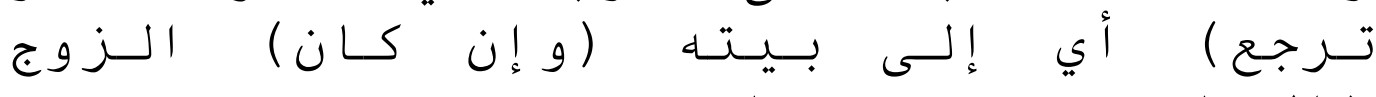

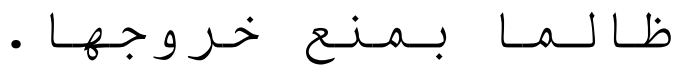

Seorang istri tidak diperkenankan keluar rumah kecuali mendapat izin suaminya. Jika ia keluar rumah tanpa izin suami, maka malaikat akan 
melaknatnya. Baik malaikat yang berada di langit dan bumi. Malaikat yang memiliki sikap kasih maupun jahat, sehingga istri tersebut mau bertaubat dan kembali ke rumah suaminya, meskipun suaminya bersifat zalim.

(Nawawi, 2015) juga menjelaskan bolehnya suami memukul istri saat istri tidak mau berhias dan menolak diajak bersetubuh:

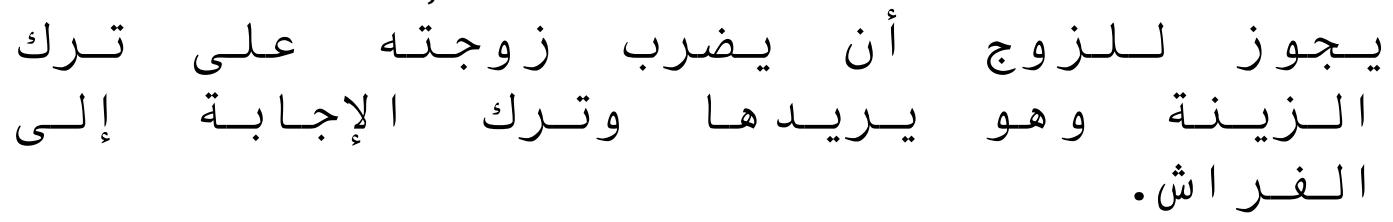

Suami diperbolehkan untuk memukul istri jika ia menolak untuk berhias atas kemauan suami. Begitu juga suami berhak memukul istri jika istri tidak mau diajak bersetubuh, sedangkan suami menghendakinya.

Kutipan-kutipan teks perilaku istri/perempuan di atas secara garis besar menjelaskan lima hal; 1) hukum istri/perempuan berkarier, 2) perlakuan istri kepada suami, 3) istri yang keluar rumah, 4) istri yang menolak berhias, dan 5) istri menolak diajak bersetubuh. Keempat poin pokok demikian merupakan generalisasi konsep perempuan dalam kitab Uqūd Al-Lijain karya Iman Nawawi. Di mana kitab tersebut ialah salah satu kitab yang menjadi rujukan para santriwati saat belajar di pesantren. Berikut untuk penjelasan lebih lanjut dalam tabel 1.

Tabel 1. Konsep Perempuan dalam Kitab Uqūd Al-Lijain

\begin{tabular}{c|llll|}
\multicolumn{1}{c}{ No } & \multicolumn{1}{c}{ Perilaku } & \multicolumn{1}{c}{ Sifat } & \multicolumn{1}{c}{ Konsekuensi } & \multicolumn{1}{c}{ Paradigma } \\
\hline 1 & Berkarier & Boleh & $\begin{array}{l}\text { Tidak Meninggalkan } \\
\text { Kewajiban }\end{array}$ & Teologi \\
2 & Melayani Suami & Harus & Berdosa & Teologi \\
3 & Keluar Rumah & Dilarang & Berdosa & Teologi dan Sosial \\
4 & Menolak Berhias & Dilarang & Suami Boleh Memukul & Teologi \\
5 & Menolak & Dilarang & Suami Boleh Memukul & Teologi dan Attitude
\end{tabular}

Kelima konsep perempuan yang digambarkan oleh Imam Nawawi dalam kitab Uqūd Al-Lijain di atas didasarkan pada hadis-hadis misogini. Sebuah hadis yang memberikan kesan benci kepada perempuan dan mendiskreditakan perempuan. Dari kelima konsep perempuan demikian maka perlu dilakukan kritik sastra feminis yang melibatkan struktur sosial dan budaya patriarki.

\section{Perempuan dalam Khazanah Kitab Uqūd Al-Lijain; Kritik Sastra Feminis}

Perempuan dalam kahazanah kitab-kitab klasik atau disebut dengan literatur Arab klasik (turas) memeliki keterkaitan erat dengan budaya patriarki. Budaya yang sangat getol pada masa abad pertengahan sehingga mempengaruhi atas reproduksi keilmuan terutama di bidang fikih/hukum Islam. Fikih menjadi literasi dan literatur primer studi Islam. Dalam Islam, peran fikih sangat mendominasi. Pada masa itu peradaban Islam disebut sebagai peradaban fikih. Dalam studi Islam, perempuan banyak diatur dalam skema fikih, sehingga literatur-literatur Islam klasik menuliskan sosok perempuan sebagai seorang yang marginal. Kritik sosial menyoroti hal demikian karena adanya hak dan kewajiban yang egaliter dan tidak memenuhi nilai moral (L. M. Wijayanti et al., 2018). 
Literatur-literatur Islam klasik tersebut seiring berjalannya waktu sampai ke Indonesia dan dikaji oleh santri yang berdomisili di pesantren. Selain ekspansi keilmuan Islam dari Timur Tengah ke nusantara, beberapa ulama nusantara yang belajar di Timur Tengah juga mempengaruhi paradigma studi Islam di pesantren. Salah satu daripada ulama tersebut adalah Imam Nawawi yang menulis kitab Uqūd Al-Lijain. Kitab tersebut hingga saat ini masih dipelajari di pesantren terutama pesantren tradisional.

Sosok perempuan dalam kitab Uqūd Al-Lijain sebagaimana dijelaskan di atas kiranya perlu dikaji secara komperhensif dalam bingkai sastra feminis. Kitab Uqūd AlLijain sebagai kitab turas yang masih dipelajari di pesantren, secara eksplisit banyak menggiring paradigma santri untuk bertindak sesuai yang dijelaskan dalam kitab tersebut. Padahal kitab tersebut merupakan karya klasik tahun 1249 Hijriyah. Jika dihitung hingga saat ini tahun 1942 Hijriyah, maka dapat dikatakan memiliki rentan yang sangat jauh. Pemikiran Imam Nawawi sangat dipengaruhi oleh mazhab tradisionalis yang ada di Timur Tengah, sehingga menuangkan diskursus perempuan di nusantara layaknya perempuan Timur Tengah. Dikuatlan lagi jika peran perempuan tersebut didasarkan pada hadis-hadis misogini. Tema-tema dalam kitab Uqūd Al-Lijain menurut hemat peneliti terangkum dalam studi fikih, tasawuf, dan akhlak. Ketiga tema demikian adalah disiplin pokok studi Islam. Hal inilah yang menggiring peneliti untuk menelaah lebih jauh atas peran perempuan dalam bingkai skolastik pesantren. Bagaimana kritik sastra feminis membaca perihal tersebut?

Peran perempuan marginal dalam kitab Uqūd Al-Lijain diskemakan dalam lima hal, yaitu; berkarier, melayani suami, keluar rumah, menolak berhias, dan menolak bersenggama. Lima perihal tersebut terkonstruksi dalam keilmuan pesantren dan dibawa santriwati khususnya saat kembali ke keluarga dan masyarakat. Perempuan identik dengan sosok yang inferior, marginal, dan terdiskreditkan atas kebijakan suami. Perempuan yang dimaksud dalam penelitian ini adalah "istri", atau yang sudah menikah. Bukan dinisbatkan pada perempuan yang belum menikah. Kemudian kritik sastra feminis yang dikaji bukan hanya mengkritik sosok perempuan dalam khazanah kitab tersebut, tetapi juga membahas latar belakang psikologi, sosial, dan budaya perempuan tersebut sehingga menjadi diskursus yang multidisiplin dari berbagai perspektif. Kritik sastra feminis sebagai frame dalam menganalisis lima hal dalam perempuan. Berikut penjelasannya;

Pertama, perempuan berkarier. Imam Nawawi telah menjelaskan perempuan berkarier dalam kitab tersebut. Menurutnya, perempuan berkarier hukumnya diperbolehkan. Hukum "boleh" dalam hal ini dinisbatkan pada bidang teologi dan fikih. Perempuan atau istri diperbolehkan berkarier dengan ketentuan tidak meninggalkan kewajibannya sebagai istri. Selagi perempuan dapat memenuhi kewajibannya sebagai istri dalam keluarga, maka pilihan berkarier tidak dipermasalahkan. Kewajiban yang dimaksud ialah menunaikan hal yang menjadi kewajiban dalam keluarga seperti melayani suami, mendidik anak, dan mengurus rumah tangga.

Secara antropologis, perempuan memiliki peran seperti laki-laki. Masalah berkarier tidak hanya terpacu untuk laki-laki. Berkarier guna memenuhi keberlangsungan hidup adalah pilihan yang tidak bisa ditawar, apalagi di masa ini. Kebutuhan hidup semakin banyak. Jika tidak dikuatkan dengan jalan berkarier antara suami dan istri, maka dikhawatirkan mempengaruhi keberlangsungan rumah tangga. Perempuan dapat berkarier sebagaimana laki-laki, menunjukkan identitas diri, dan memiliki peran publik. Eksistensi perempuan sebagai tokoh dan peran publik dalam budaya populer tidak hanya sebagai pelengkap. Ia berhak memiliki posisi yang sama dengan laki-laki tanpa memandang latar belakang sosial. Dengan adanya persamaan ini, 
perempuan mendapatkan hak yang setara dengan laki-laki tanpa adanya unsur diskriminasi, diskredit, dan marginalisasi.

Kedua, melayani suami. Hal tersebut merupakan hal privasi yang hanya diketahui oleh pasangan suami istri. Dalam kitab Uqūd Al-Lijain, Imam Nawawi menjelaskan perempuan harus melayani laki-laki dalam segala hal. Melayani sisi jasmani dan rohani. Pernyataan ini didasarkan dengan paradigma teologi, di mana perempuan yang tidak mau melayani suami dihukumi berdosa. Perempuan senantiasa taat atas kebijakan laki-laki. Tidak dapat menolak kecuali memang melanggar ketentuan yang digariskan agama. Secara teologis, perempuan yang melayani suami dalam segala hal akan mendapat pahala dari Tuhan. Eksistensi ini yang menggiring paradigma perempuan untuk selalu mematuhi suami dalam segala hal tanpa mempertimbangkan sisi positif dan negatif.

Paradigma perempuan harus melayani suami di manapun dan kapanpun telah mengakar kuat dalam santriwati di pesantren. Dapat dilihat saat mereka lulus dari pesantren dan melangsungkan pernikahan, begitu tampak perilaku salehah mereka. Mereka terlihat taat kepada suami dalam perihal perkataan dan perbuatan, melaksanakan seluruh kebijakan suami tanpa didasarkan pertimbangan yang matang. Laki-laki (suami) memiliki otoritas dan bersifat superior dalam membina rumah tangga. Perempuan (istri) ialah pelayan suami yang sewaktu-waktu diperlukan harus siap. Jika melihat peran dan fungsi antara laki-laki dan perempuan dalam, maka suami memiliki otoritas dan bersifat superior. Perempuan tidak banyak memiliki peran dan bersifat inferior.

Dalam budaya populer, tidak hanya perempuan yang berkewajiban melayani suami. Sebaliknya laki-laki ada yang melayani istri karena berbagai faktor. Perkembangan ilmu pengetahuan, teknologi, pesatnya pertumbuhan ekonomi, serta konstruksi pranata sosial yang kini semakin bergeser dari skolastik menuju modernisasi, merupakan faktorfaktor kunci dalam perubahan sosial. Saat ini banyak perempuan yang mengambil alih peran laki-laki. Tidak hanya dalam kepemimpinan publik, tetapi juga dalam konstruksi sosial (D. E. Wijayanti, 2020). Perempuan banyak berperan di masyarakat dan menentukan kebijakan. Peran perempuan dalam kitab Uqūd Al-Lijain yang dituntut selalu siap melayani suami, kini kurang tepat jika diterapkan dalam budaya populer. Perempuan banyak beraktivitas guna menopang kesejahteraan keluarga. Jika suami lemah, maka suami berkewajiban melayani istri. Saat ini didapati perempuan yang menjadi agent of change dalam perubahan sosial, semisal yang berkecimpung dalam bidang filantropi, fundrising, organisasi masyarakat, dan komunikasi publik. Peran perempuan dalam berbagai bidang tersebut bukan berarti mendistorsi peran laki-laki, justru menguatkan peran laki-laki. Sehingga antara laki-laki dan perempuan mempunyai kewajiban yang sama yaitu saling melayani. Perempuan yang harus melayani suami sebagaimana diungkap Nawawi dalam kitab tersebut dinilai tepat di era skolastik-tradisionalis, bukan di era modernisasi-reformis seperti saat ini.

Ketiga, perempuan yang keluar rumah. Nawawi dalam kitab Uqūd Al-Lijain telah menjelaskan attitude perempuan yang keluar rumah. Beliau menyebut perempuan (istri) yang keluar rumah tanpa seizin suami maka dihukum berdosa. Nawawi menjustfikasi perempuan dengan sudut pandang teologi yang lebih spesifik dalam hal syariat Islam. Nawawi memberikan gambaran bahwa perempuan yang keluar rumah tanpa seizin suami dapat menjadi fitnah. Belum lagi jika terjadi suatu hal yang tidak diinginkan. Lagipula attitude perempuan yang mengumbar diri dengan keluar rumah dirasa tidak pantas di masa itu, karena perempuan adalah makhluk yang senantiasa tertutup di masyarakat. Namun ada Sebagian perempuan yang masih menerapkan paradigma tersebut hingga saat ini. Mereka tidak akan keluar rumah tanpa seizin suami, bahkan jika suami tidak ada di rumah. Entah apa nanti yang akan terjadi, mereka tidak peduli. Kuatnya hadis-hadis 
misogini dalam kitab Uqūd Al-Lijain yang menjelaskan akibat perempuan keluar rumah tanpa seizin suami menjadi faktor utama mereka melakukan hal tersebut. Padahal hadishadis misogini terjadi lantaran sebab-sebab tertentu, bukan menggeneralisasi dalam semua keadaan. Hadis-hadis misogini juga perlu untuk diteliti (takhrij) dalam sisi sanad dan matan.

Kritik sastra feminis menyoroti perihal perempuan yang masih berpegang teguh dalam hal demikian. Saat ini banyak perempuan yang keluar rumah tanpa seizin suami secara eksplisit. Misalnya perempuan berkarier yang dituntut disiplin dalam dunia kerja, serta diharuskan masuk pagi tanpa terlambat. Perempuan tersebut menjadi tulang punggung keluarga lantaran hasil nafkah yang diberikan suami diarasa kurang untuk menyuplai kebutuhan keluarga. Maka perempuan demikian memiliki otoritas dan peran yang sama seperti suami, yakni sama-sama mencari nafkah untuk kesejahteraan keluarga. Perihal izin kepada suami menurut hemat peneliti adalah berkaitan dengan attitude keluarga. Bukan berarti mengisolasi perempuan di rumah dan tidak memiliki kebebasan berekspresi di luar rumah tanpa izin suami. Mereka dapat saling dialog guna menentukan yang terbaik bagi kehidupan rumah tangga. Perempuan yang tidak boleh keluar rumah tanpa izin suami dirasa tepat untuk masa klasik, karena berkaitan dengan attitude dan budaya patriarki. Attitude perempuan dalam menjalankan hal demikian masih relevan di masa modern ini. Dalam arti perempuan tidak terisolasi dalam berekspresi seperti masa klasik.

Keempat, memnolak berhias. Nawawi menjelaskan dalam kitab Uqūd Al-Lijain bahwa perempuan (istri) yang menolak berhias saat disuruh suami, maka laki-laki (suami) boleh memukul. Budaya patriarki menempatkan laki-laki sebagai makhluk yang superior, sehingga ia berhak melakukan apapun tanpa persetujuan perempuan. Laki-laki yang diperbolehkan memukul perempuan menurut Nawawi didasarkan pada paradigma fikih (hukum Islam). Maksud diperbolehkannya memukul adalah dengan tujuan memberikan edukasi. Bukan lantaran benci kepada perempuan. Banyak keterangan turas lainnya yang berkaitan dengan diperbolehkannya laki-laki memukul perempuan bermisi edukasi. Seperti dijelaskan dalam kitab 'I'ānah al-Ţalibinn. Dalam kitab tersebut dijelaskan laki-laki diperbolehkan memukul istri dengan tujuan mendidik saat istri tidak dapat diatur dan diberi pengarahan (هاشم \& الدمياطي/البكري, 2018). Dari keterangan tersebut dapat dipahami bahwa laki-laki diperbolehkan memukul perempuan.

Berhias bagi perempuan adalah hak. Perempuan diperbolehkan menghias diri secantik mungkin sesuai dengan kehendaknya. Laki-laki tidak diperkenankan memaksa perempuan untuk selalu berhias, terlebih memukul. Di masa ini perempuan sudah dimanjakan dengan berbagai alat kecantikan. Hal tersebut membuat perempuan sadar diri dan lebih termotivasi dalam berhias. Belum lagi saat mereka akan menghadiri kegiatan-kegiatan publik. Maka tanpa disuruh laki-lakipun mereka sudah berhias dengan sendirinya. Berbeda di era skolastik yang mengisolasi perempuan dalam berhias. Perempuan diperbolehkan berhias hanya di depan suami. Bukan untuk umum terlebih khalayak publik. Saat ini perempuan memiliki tanggung jawab dan peran seperti lak-laki. Mereka banyak yang beraktivitas di luar. Sehingga berpenampilan yang baik ialah kewajiban agar perempuan memiliki harga diri. Tidak terhina lantaran penampilan yang kurang baik. Kemudian permasalahan diperbolehkannya suami memukul di saat ini dinilai juga sudah tidak berlaku, karena hukum positif tidak memperbolehkan adanya KDRT. Bagi yang melanggar dapat diproses hukum. Hal tersebut semata-mata sebagai kritik sosial dan melindungi hak perempuan. Di mana mereka berhak memiliki perlindungan yang setara sebagai warga negara. (Murdianto, 2020) menjelaskan terciptanya keluarga yang harmonis tanpa ada KDRT adalah misi agama. Adanya perilaku 
destruktif dapat menghambat terciptanya hal demikian, karena tidak terciptanya empati dan cinta kasih dalam pasangan.

Kelima, menolak senggama. Perempuan yang menolak senggama diperbolehkan dipukul. Laki-laki (suami) memiliki otoritas untuk dilayani perempuan. Ia berhak memerintah perempuan sesuai kehendaknya. Nawawi menjelaskan bahwa perempuan (istri) adalah hak atas suami. Perempuan harus senantiasa melayani suami terlebih kebutuhan biologis. Bagi yang melanggar, maka malaikat akan melaknat perempuan tersebut. Dalil ini yang dinisbatkan Nawawi dengan kerangka teologi. Sehingga ia menyatakan peran perempuan masih terikat oleh kebijakan suami. Pernyataan Nawawi ini masih diadopsi oleh sebagian perempuan hingga saat ini.

Jika melihat pernyataan di atas, perempuan manjadi makhluk yang termarginalkan. Ia tidak memiliki hak penuh atas kehendak dirinya. Padahal hak ialah suatu hal yang wajib diterima dalam diri seorang. Di masa ini sudah hilang sifat paksamemaksa. Laki-laki dan perempuan sama-sama dilindungi hukum. Sifat paksa-memaksa dikhawatirkan menjerumuskan pada tindak kriminal, membuat rumah tangga goyah, dan ditakutkan terjadi perceraian. Perempuan memiliki hak yang sama untuk dilayani termasuk kebutuhan biologis. Adanya sifat saling memahami antara laki-laki dan perempuan dapat menghilangkan sifat paksa-memaksa. Apalagi saat ini banyak perempuan yang beraktivitas sebagaimana laki-laki. Entah karena faktor ekonomi atau yang lain, sehingga hak dan kewajiban setiap pasangan dapat didialogkan tanpa menggunakan unsur kekerasan.

\section{Simpulan}

Kitab 'Uqūd Al-Lijain sebagai salah satu kitab turas banyak menjelaskan ketidaksetaraan peran perempuan dalam keluarga, masyarakat, dan sosial seperti masalah perempuan berkarier, melayani suami, keluar rumah, menolak berhias, dan bersenggama. Imam Nawawi menulis kitab tersebut pada masa tradionalis-skolastik, sehingga teks yang tertulis masih memiliki intervensi dengan budaya patriarki. Belum lagi corak pendidikan Timur Tengah yang diembannya dan menjadikan paradigma ketidaksetaraan perempuan masih terdominasi di saat itu.

Menyikapi teks yang ditulis Nawawi, kritik sastra feminis memberikan komentar bahwa perilaku-perilaku yang mendiskreditkan dan memposisikan perempuan sebagai makhluk marginal sudah tidak relevan di masa modernisasi. Hal ini dikarenakan perkembangan ilmu pengetahuan dan teknologi semakin cepat, pertumbuhan ekonomi semakin meningkat, pranata dan strukur sosial berkembang yang membawa budaya populer semakin diadopsi oleh masyarakat. Perempuan memiliki peran yang sama dengan laki-laki. Saat ini perempuan tidak dapat diisolasi seperti masa klasik, karena perempuan banyak mengambil alih peran laki-laki dalam berbagai bidang.

\section{Ucapan Terima Kasih}




\section{Daftar Pustaka}

Akib, M. N. (2019). Doktrin Pesantren terhadap Perempuan (Kajian Terhadap Kitab-kitab dan Realitas Perempuan di Dalam Pesantren). IQRA Jurnal Ilmu Kependidikan Dan Keislaman, 3(1), 34-53.

Endaswara, S. (2011). Metodologi Penelitian Sastra. Niaga Swadaya.

Ernst, W., \& Horwath, I. (2014). Gender in Science and Technology: Interdisciplinary Approaches. transcript Verlag. https://books.google.co.id/books?id=sHWiBQAAQBAJ

Gandhi, L. (2020). Postcolonial Theory: A critical introduction. Taylor \& Francis. https://books.google.co.id/books?id=aVLzDwAAQBAJ

Goodman, L. (2013). Literature and Gender. Taylor \& Francis. https://books.google.co.id/books?id=IOmnbJRbx5cC

Humm, M. (2003). The Dictionary of Feminist Theory. Edinburgh University Press. https://books.google.co.id/books?id=5AB2PwAACAAJ

Madsen, D. L. (2000). Feminist Theory and Literary Practice. Pluto Press. https://books.google.co.id/books?id=moZZDDFAFvsC

Murdianto, M. (2020). Khazanah Folklor untuk Menumbuhkan Karakter Empati dan Cinta Kasih. Aphorisme: Journal of Arabic Language, Literature, and Education, 1(2), 92104. https://doi.org/10.37680/aphorisme.v1i2.474

Naomi, R. W. (1994). Fire with Fire; The New Female Power and How it Will Change The 21st Century. Fawcett Columbine.

Nawawi, S. (2015). شرح عقود اللجبن في بيان حقوق الزووجين Dar Al Kotob Al Ilmiyah دار الكتب العلمية. https://books.google.co.id/books?id=5fZHDwAAQBAJ

Nuroniyah, W. (2019). Feminisme dalam Pesantren: Narasi Pemberdayaan Perempuan Di Pondok Pesantren Buntet Cirebon. Equalita: Jurnal Pusat Studi Gender Dan Anak, 1(1), 142. https://doi.org/10.24235/equalita.v1i1.5163

Prasetiawan, A. Y., \& Lis, S. (2019). Kepemimpinan Perempuan dalam Pesantren. Yinyang: Jurnal Studi Islam Gender Dan Anak, 14(1), 39-69. https://doi.org/10.24090/yinyang.v14i1.2874

Ratnasari, D. (2016). Pemberdayaan Perempuan Dalam Pendidikan Pesantren. 'Anil Islam: Jurnal Kebudayaan Dan Ilmu Keislaman, 9(1), 122-147.

Rokhmansyah, A. (2014). Studi dan Pengkajian Sastra. Graha Ilmu.

Soenarjati. (2010). Kritik Sastra Feminis. Gramedia Pustaka Utama.

Sugihastuti, S. (2002). Kritik sastra feminis: teori dan aplikasinya. Pustaka Pelajar. https://books.google.co.id/books?id=WUXaAAAAMAAJ

Tabroni, R. (2019). Sastra Pesantren dalam Lintasan Sejarah. Jurnal Tamaddun: Jurnal $\begin{array}{llll}\text { Sejarah Dan } & \text { Kebudayaan }\end{array}$ https://doi.org/10.24235/tamaddun.v7i2.5504

Tong, R. (2013). Feminist Thought: A Comprehensive Introduction. Taylor \& Francis. https://books.google.co.id/books?id=cv5EAQAAQBAJ

Wijayanti, D. E. (2020). Perjuangan Perempuan pada Masa Pergolakan Politik Indonesia Tahun 1965 dalam Novel Gadis Jakarta Karya Najib Kaelani dan Novel Amba Karya Laksmi Pamuntjak. Aphorisme: Journal of Arabic Language, Literature, and Education, 1(2), 73-91. https://doi.org/10.37680/aphorisme.v1i2.402

Wijayanti, L. M., Suharto, T., \& Soleh, D. R. (2018). Kritik Sosial dan Nilai Moral dalam Stand Up Comedy Indonesia Episode 7 Di Televisi Nasional Kompas (Analisis Wacana Tekstual dan Kontekstual. Widyabastra: Jurnal Ilmiah Pembelajaran Bahasa Dan Sastra Indonesia, 6(2), 21-33. 
Yudono. (2009). Pengkajian Kritik Sastra Indonesia. Grasindo.

هانشم, م. س., \& الدمباطي/البكري, أ. ب. ع. ب. م. ش. (2018). حاثشية إعانة الطالبين على حل ألفاظ فتح الدعبين الثرح

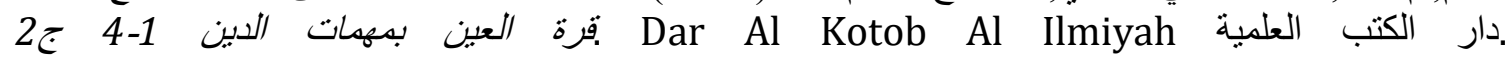
https://books.google.co.id/books?id=In2DDwAAQBAJ 